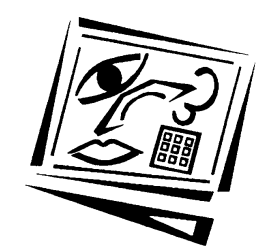

\title{
Adoption of innovative e-learning support for teaching: A multiple case study at the University of Waikato
}

\author{
E. Marcia Johnson, Bronwen Cowie, Willem De Lange, Garry Falloon, \\ Craig Hight and Elaine Khoo \\ The University of Waikato
}

\begin{abstract}
In response to recent social, economic, and pedagogical challenges to tertiary-level teaching and learning, universities are increasingly investigating and adopting elearning as a way to engage and motivate students. This paper reports on the first year of a two-year (2009-2010) qualitative multiple case study research project in New Zealand. Using perspectives from activity theory and the scholarship of teaching, the research has the overall goal of documenting, developing, and disseminating effective and innovative practice in which e-learning plays an important role in tertiary teaching. A "snapshot" of each of the four 2009 cases and focused findings within and across cases are provided. This is followed by an overall discussion of the context, "within" and "across" case themes, and implications of the research.
\end{abstract}

\section{Introduction and background to the research}

In New Zealand, as in other developed nations, the tertiary sector is experiencing challenges to teaching and learning practice due to the increased diversity of the student body, changes to how universities are funded (Russell, 2007), issues relating to student retention and completion (Government of New Zealand, 2006), and student satisfaction with learning opportunities (Krause, Hartley, James \& McInnis, 2005). As a way to address these concerns, universities are increasingly investigating and adopting e-learning in order to engage and motivate students, to provide additional support for teachers, and to extend learning opportunities beyond classroom walls. However, the incorporation of e-learning is always mediated by political, technological, financial, workload, and student learning implications (Selander, 2008), and universities need to understand how to close the participatory gap to ensure that e-learning is equitably and effectively used across disciplines (Whitworth, 2006). While insights from overseas studies can guide and inform e-learning practice within New Zealand universities, the importance of developing deep understanding of local contexts and practices cannot be underestimated (Divaharan \& Lim, 2010). This paper reports on the first year of a two-year (2009-2010) qualitative, multiple case study, elearning research project in New Zealand (Johnson, Cowie, DeLange, \& Hight, 2009). For the purposes of the project, we define e-learning as resources and activities using the Internet and the World Wide Web (web) to support teaching and learning.

The project had the interpretivist research goals of documenting, developing, and disseminating effective and innovative practice in which e-learning plays an important role. The overarching aim was to leverage pedagogical change, close participatory gaps for students and lecturers, and develop and enhance a cross-university 
educational research culture to inform teaching practices. Reeves, McKenney and Herrington (2011) in their discussion of educational design research state that interpretivist research is characterised by descriptions and interpretations of key phenomena related to teaching and learning processes and focuses "on the bigger picture of lessons learned and not just the immediately developed results" (p. 61). The interpretive methodology is consistent with the intention of uncovering the significance of events as experienced by research participants (Lather, 1992; Maykut \& Morehouse, 1994). This epistemology is further congruent with the perspective that knowledge is co-constructed through dialogue and other forms of joint activity.

During the first year (2009), case studies in four contrasting teaching areas (Earth and Ocean Science, Education, Screen and Media Studies, and pre-degree Academic Literacy) were undertaken to investigate pedagogical practices within blended and virtual learning environments. While the physical learning "place" remained the university, the learning "spaces", both physical and virtual within which students and teachers functioned, changed and reflected differing pedagogical and technological needs across the teaching areas and cohorts. Noteworthy is that none of the cases in this project was an "intervention", by which we mean external ideas being introduced into courses in order to see what might happen, but rather they represent the types of e-learning approaches and pedagogical changes the lecturers wanted to implement. As such we would characterise the e-learning approaches as lecturer-driven refinements of pedagogy in order to inform and improve practice. This paper reports on student and lecturer perspectives of what occurred both within and across the case studies.

\section{Research method and analytical framework}

The project was guided by one overall research question that asked: "How are different lecturers/groups exploiting the potential of e-learning to support tertiary level student learning?" The research included multiple case studies and used a multimethod approach to data collection, in which qualitative text-based and quantitative (numerical) survey data were collected. Divaharan and Lim (2010), citing Yin (2003) in their discussion of case study research within e-learning environments, state: "multiple case study research is helpful for answering 'how' questions, which are more explanatory, especially when the researcher had minimum effect on the events" ( $p$. 745). Moreover, multiple case study research can be effective for illuminating different perspectives on pedagogical issues, which in turn can inform practice (Divaharan \& Lim, 2010). Lecturer reflections were obtained through key informant interviews, while both student and tutor feedback was gathered through facilitated focus group discussions. In addition, student reflections about their e-learning practices within their own learning (rather than in their personal activities) were gathered through a common online survey, the design of which was informed by other relevant studies of e-learning implementation (Salaway, Caruso \& Nelson, 2007).

The main explanatory framework for the study is activity theory, with particular reference to mediation and how it is manifested through the constraints and affordances identified at the research sites (Bakhurst, 2009; Cole \& Engestrom, 1993; McGrenere \& Ho, 2000). Research that is grounded in activity theory focuses on the interactions of people, tasks, and mediating tools, rather than on individual behaviours, performance, or mental models. This paradigm is particularly suited to the activity of complex organisations, or in this project, to development of nuanced understanding both within and across case studies, as multiple perspectives are 
identified and explained. A key concept of activity theory is that cultural mediation shapes not only the outcome of an activity, but importantly, the subject using the artifact. Mediation has a "...recursive, bidirectional effect; mediated activity simultaneously modifies both the environment and the subject" (Cole \& Engestrom, 1993, p. 9). Further, mediation relates to the idea that human behaviour is far more complex than a simple reaction to a stimulus, but that all human activity is shaped by "artifacts that are created to prompt or modulate action" (Bakhurst, 2009, p. 199). In this project, systemic data collection and analyses within and across the case studies facilitated the identification of technological and cultural tools and consideration of how they affected multiple teacher and student participants.

Consistent with qualitative research, a constant comparison approach to data analysis was followed (Lincoln \& Guba, 1985), but there have been some key differences. The individual case studies in the project ran during different teaching terms and although some cases did occur simultaneously, not all case studies ran at the same time. Regardless of who was researching, the research team (comprising the team leaders, lecturers teaching in the case studies, research assistant, and representatives from the university e-learning support group) met regularly (every two to three weeks throughout the year) and as many members as possible attended. As interview and focus group data were collected within individual case studies, the team leaders and research assistant (separately) read and re-read the text-based transcripts. Through a process of inductive reasoning, emergent themes within cases were identified (Braun \& Clarke, 2006) and then reported, discussed, and debated by the team at the regular project meetings. Such discussion facilitated the understanding of both particular ("within case") and generic ("across case") themes. Finally, at the end of the first year of the research, the team held a discussion retreat day to consolidate key overall themes emerging from the project.

\section{Limitations of the research}

The participants in this study represent a convenience sample of lecturers and students in one tertiary level context and are not representative of possible participants across different university settings. Nevertheless, a textured view of instructional practices and multiple participants' beliefs, expectations, and reactions to the implementation of different e-learning approaches within that setting was obtained and, importantly, is consistent with research findings reported elsewhere (Convery, 2009; Crook, 2008; Helsper \& Eynon, 2009; Means, Toyama, Murphy, Bakia \& Jones, 2010). While the qualitative case study findings reported here cannot be generalised to a wider population, they can be related to similar higher education teaching contexts elsewhere and can provide nuanced insights into mediation of self and practice through technology in a tertiary environment. However, a key limitation of this study is the possible omission of relevant ideas and perspectives from people who were not included.

\section{Description of the four case studies}

The four case studies were based in Earth and Ocean Sciences, Education, Screen and Media Studies, and a pre-degree university academic skills preparation program. Overall, there were approximately 400 students across the cases. A brief overview of the context of the individual case studies is included in Table 1 with detailed description of the cases following. 
Table 1: Context of the case studies

\begin{tabular}{|l|l|l|l|l|}
\hline \multicolumn{1}{|c|}{$\begin{array}{c}\text { Teaching } \\
\text { area }\end{array}$} & \multicolumn{1}{|c|}{$\begin{array}{c}\text { Learning } \\
\text { context }\end{array}$} & \multicolumn{1}{c|}{$\begin{array}{c}\text { Class } \\
\text { size }\end{array}$} & \multicolumn{1}{c|}{$\begin{array}{c}\text { E-learning } \\
\text { tool adopted }\end{array}$} & \multicolumn{1}{c|}{$\begin{array}{c}\text { Purpose for } \\
\text { e-learning tool }\end{array}$} \\
\hline $\begin{array}{l}\text { Earth and Ocean } \\
\text { Sciences }\end{array}$ & $\begin{array}{l}\text { First year } \\
\text { undergraduate } \\
\text { (blended learning) }\end{array}$ & $\begin{array}{l}\text { Large } \\
\text { (150+ } \\
\text { students) }\end{array}$ & $\begin{array}{l}\text { Google Earth } \\
\text { (freeware) }\end{array}$ & $\begin{array}{l}\text { Developing visual } \\
\text { spatial thinking skills }\end{array}$ \\
\hline $\begin{array}{l}\text { Education } \\
\text { (Professional } \\
\text { Studies) }\end{array}$ & $\begin{array}{l}\text { Postgraduate } \\
\text { (virtual / fully } \\
\text { online) }\end{array}$ & $\begin{array}{l}\text { Small (<10 } \\
\text { students) }\end{array}$ & $\begin{array}{l}\text { Virtual classroom } \\
\text { (Adobe Connect - } \\
\text { (proprietary software) } \\
\text { Moodle (open source) }\end{array}$ & $\begin{array}{l}\text { Bridging transactional } \\
\text { distance; developing a } \\
\text { learning community }\end{array}$ \\
\hline $\begin{array}{l}\text { Screen and Media } \\
\text { Studies }\end{array}$ & $\begin{array}{l}\text { First year } \\
\text { undergraduate } \\
\text { (blended learning) }\end{array}$ & $\begin{array}{l}\text { Large } \\
(150+ \\
\text { students) }\end{array}$ & $\begin{array}{l}\text { GNU Image } \\
\text { Manipulation Program } \\
\text { (GIMP) (open source) } \\
\text { Moodle (open source) }\end{array}$ & $\begin{array}{l}\text { Developing visual } \\
\text { image manipulation } \\
\text { skills }\end{array}$ \\
\hline $\begin{array}{l}\text { University prepa- } \\
\text { ration (academic } \\
\text { literacy) }\end{array}$ & $\begin{array}{l}\text { Pre-degree } \\
\text { (blended learning) }\end{array}$ & $\begin{array}{l}\text { Large } \\
\text { (100+ } \\
\text { students) }\end{array}$ & $\begin{array}{l}\text { Moodle } \\
\text { (open source) }\end{array}$ & $\begin{array}{l}\text { Developing basic } \\
\text { academic literacy skills }\end{array}$ \\
\hline
\end{tabular}

\section{Earth and Ocean Sciences and the use of Google Earth}

Key goals of the Earth and Ocean Science degree are to develop students' geoscientific thinking and practical skills - specifically their ability to think spatially (Black, 2005), develop a geoscientist's understanding of time, view the earth as a complex and interrelated system, and develop the necessary skills to conduct fieldwork. Kastens, Manduca, Cervato, Frodeman, Goodwin, Liben, Mogk, Spangler, Stillings and Titus (2009) discuss pedagogical challenges facing geoscientist educators and state that "two key features of geoscientists' temporal thinking distinguish them from the general population: They take a long view of time, and they expect low frequency, high impact events" (p. 265). Undergraduate courses in Earth and Ocean Sciences make frequent reference to landforms, particularly around New Zealand, yet, as the student population has become more diverse, an increasing number of learners have had no personal experience of the locations being studied. This lack of familiarity with the local physical environment limits students' ability to maximise learning experiences in the field. Artifacts, such as maps and aerial photographs are used with first year students, but the diversity of cultural and physical abilities in classes has made it difficult to ensure that all students progress at a satisfactory rate. Previously, various multimedia, computer-based methods, including virtual field trips had been trialed as tools to develop students' skills, but had been of minimal success due to cost, technological requirements, and user interface complexity.

Freeware such as Google Earth (GE) now provides an economical and simple interface with relatively low technological requirements. Accessing GE on university or personal computers is straightforward and the software itself is easy to use. Also, with the recent release of Google Streets for New Zealand, there exist a large number of web overlays for local landforms that can facilitate three-dimensional visualisation (spatial thinking) with access to environmental data such as glacier extent and real-time wave and weather conditions. Moreover, GE data is updated continuously so that the virtual lab-based resources are much more current than more traditional textbook or other print-based materials.

This case study investigated the impact of a new pedagogical approach combining physical and virtual activities. Students attended lab sessions during which they 
utilised GE, in conjunction with maps and aerial photos, to examine landforms and other physical objects around the university campus and nearby locations. The lab work was intended to develop sufficient skills with GE to allow students to use linked KMZ files in Moodle to "visit" locations referenced in lectures and labs prior to their fieldtrip to Raglan, a New Zealand West Coast ocean beach town. As part of the fieldtrip activity, students were expected to compare their expectations, determined from the virtual "pre-visit", to the physical reality of the site, students could also "revisit" locations later through GE. The lecturer believed that having an ability to enhance physical activities through pre-planning, to compare measurements of spaces obtained in GE with the reality of outdoor places, and to review fieldwork could supplement the pedagogical richness of students' experience and contribute to their development of visual spatial thinking.

\section{Professional education and the use of a virtual classroom (VC)}

All communication with students who are studying for their Master of Education degree in fully online mode is made through the university's learning management system (Moodle). While online, asynchronous distance teaching through Moodle supports flexibility in learning, students' physical separation can be disadvantageous for some types of learners. For example, in an online learning environment disparate groups can sometimes fail to develop into a coherent, effective learning community, with the result that students' learning and course completion rates suffer. Kanuka and Jugdev (2006) in their study of the use of synchronous communication software (video conferencing and Elluminate Live!) to create a virtual classroom (VC) environment found that such tools lead to the establishment of better-performing communities of practice amongst postgraduate students, which in turn lead to increased overall satisfaction with the online learning experience.

In this case study, the lecturer explored if and how a VC environment could assist in the development of a well-functioning e-learning community and reduce perceived transactional distance amongst participants (Moore, 1997; Thorpe, 2008). The lecturer wanted to assess whether or not participants perceived added value from the shared online experience, while at the same time identify any issues or barriers, which might affect more widespread adoption of VC technology within other fully online distance education programs at the university. The New Zealand Ministry of Education's Adobe Connect Pro server was used along with a publicly available audio-conference facility to create the VC environment. Adobe Connect is a web-based synchronous communication application that allows users to login to a virtual meeting room and participate in real time meetings, in much the same manner as attending a meeting in a defined physical space. The environment supports various facilities often found in traditional meeting rooms, including web delivered video, an interactive shared whiteboard, chat functionality, and shared document and application access. It also allows users to share, collaborate on, and present work to other meeting participants.

The students' task was to develop, implement, and evaluate an e-learning initiative of their choice, based on a personal or institutional need or opportunity. The projects could be broad, encompassing both e-learning and the use of e-learning resources in the conventional classroom. During the students' first VC session they presented their initial project ideas and received peer and lecturer feedback relating to its goals and implementation approach. The second VC session required students to outline specific steps they intended to take to implement and evaluate their e-learning initiative. 


\section{Screen and Media Studies and the use of GNU Image Manipulation Program}

Increasingly the Screen and Media Studies program expects students at second and third year levels to have generic computer literacy skills that extend beyond simple word processing. The learning of skills inherent to creative software is closely integrated into conceptual work in media studies and is required for students to complete assessments. The challenge for the department had been to design first-year courses that could provide a foundation in basic image processing skills, within a curriculum that must address a wide range of students' existing computing competencies and experience. In addition there existed the practical constraints of large class sizes and the fact that use of proprietary software (Adobe Photoshop) had restricted teaching to the few on-campus computing labs in which the licensed software was installed.

In previous years, in order to address these constraints, tight scheduling of lab time for groups of students was required. During multiple face to face instructional sessions, all students worked through the same set of introductory Adobe Photoshop concepts, regardless of whether their image processing skills were basic or advanced. Given the range of students' computing proficiencies, some of them found the image production task overwhelmingly difficult, while others were bored by the perceived simplicity of it. Also, due to lab and software constraints, there was no flexibility in the timing of assessments as the lecturer had to keep large groups of students moving both through the labs and through curriculum concepts.

This case study involved the adaptation of the existing curriculum to one in which an open source software (OSS) graphics package, the GNU Image Manipulation Program (GIMP) and Moodle were used. The lecturer believed that there would be several advantages to the new blended instructional environment. One was that because GIMP and Moodle would be used, the revised curriculum could be tailored to differentiate between existing skill levels of incoming students. Resources designed for more confident or experienced computer users were moved into the Moodle environment, and students could work through them at their own pace, during their own time. In addition, the assignment due date for the compulsory GIMP layering assignment, given to students at the outset of the course and designed to help them acquire the basic graphical skills they would need throughout their assessed work, was removed. Face to face instructional time in the computer lab could then be devoted to helping less experienced students develop the requisite introductory image processing skills to complete course assignments. Also, the GIMP and Moodle software tools mesh well with conceptual material at first-year level by exemplifying OSS developments within digital media. Finally, through this new blended approach the physical instructional space could be used to support students who needed more face to face assistance, while overall, students could develop academic literacy skills such as self-assessment and time management.

\section{A University pre-degree preparation program (academic literacy)}

The Certificate of University Preparation (CUP) program is a one-semester set of predegree academic literacy skills preparatory courses to assist school leavers who have just missed achieving university entrance, or people who have been away from formal study for some time and feel unsure about their academic preparedness. The predominant method of teaching is face to face, classroom based instruction, five days 
a week. Although students in the program are familiar with the use of computers and hand-held mobile technology, they often struggle to acquire basic academic literacy skills such as paraphrasing, conducting research, referencing, and structuring information into cohesive prose. Moreover, lack of confidence to acquire such academic skills is a major issue faced by many of these bridging students.

Student Learning, an academic skills development unit at the University, has designed and developed a range of interactive online workshops within Moodle to help students learn about, practice, and improve their basic academic literacy skills. Previously, learning development at the university had been provided solely through face to face meetings with students, however, the online workshops have been effective for extending Student Learning's services by synchronising physical and virtual environments (Johnson, Haines \& Strang, 2009). Moreover, such an approach is entirely consistent with current thinking about the role of e-learning to support the development of academic literacies within higher education (Goodfellow, 2007) and extend students opportunities to access resources on demand (Wesche, 2009).

This case study focused on the collaborative development of introductory academic literacy skills, in particular the essay writing process, paraphrasing, and time management for pre-degree students through the use of interactive online workshops to supplement face to face teaching. It was intended that the online resources would be used to extend and reinforce conventional classroom-based instructional processes while CUP and Student Learning tutors could collaboratively enhance pathways into degree study for the students. It was also intended that the interactive online workshops could foster a sense of independence and autonomy amongst the predegree students - skills crucial for university degree study.

\section{Findings from the four case studies}

The activity theory framework has helped us identify the mediating affects of the elearning approaches within each case study, which are framed here within discussion of constraints and affordances. In addition, Murphy and Rodriguez-Manzanares (2008), in their exploration of activity theory within e-learning research, identify multiple ways in which the theory is useful for illuminating contradictions in teachers' beliefs and actions, students' resistance to the use of new tools for their learning, and changes in classroom processes.

\section{Earth and Ocean Sciences}

\section{Constraints}

Students reported such constraints as initial confusion about the objectives of the GEbased tasks, limited access to computer labs, time constraints related to the workload expectations for students, and insufficient numbers of lab tutors to assist them as they learned how to use the software. Although one could argue that GE is freeware and could be accessed anytime, anywhere (with the consequent assumption that it is easy to use), in fact the students commented on the need for explicit guidance on how to use GE to complete the assignments.

I found it quite frustrating using GE ... they expected a certain level of knowledge, of zooming in and out; I didn't have it. There weren't enough computers. I found the whole GE thing frustrating. 
The pre-lab questions were "kind of daunting ... I thought how on earth am I going to do that, not knowing GE, not knowing that you can get in and put a point in and measure elevation scales on the screen. Really, really daunting. I didn't know what I was doing".

In contrast, the lecturer had a different view about the initial difficulty of using GE.

I had demonstrators to help the students with GE but they found that almost every student didn't need help, or they talked with the person next to them and worked it out. So there were a few, primarily some of the international students weren't familiar with the computer needed a little bit of help - along the lines of "do this" to "turn it on," "that is what this does," and they were away, looking at their own house and their friend's house and various other things as well.

\section{Affordances}

In spite of the initial difficulties, there were a number of key affordances to the elearning approach, particularly as regards the development of visual spatial thinking. All students agreed that once they had acquired facility with GE, they enjoyed it and experimented with it far beyond what was required for the course.

It makes it easier because you' re actually visualising stuff, like real stuff. A topography map has mountains and that's nice, but you actually see real features [on GE], an old flood [plain] and bits of deposits. You can't see that on maps.

It was best when we were looking at beaches cause you could turn it onto its side and work out how steep the geography behind it was instead of looking straight down on it.

From the lecturer's perspective, GE proved useful for illustrating spatial relationships between objects visible in images.

The advantage of GE is that you can play around with it. You can change the view angle... GE in this course is really to get people to get some experience with it, but also to show the relationships between landforms and place.

The lecturer did identify some limitations of GE, particularly for visualising topography, soils, geology, vegetation, and hydrology, and as a result incorporated a Geographic Information Systems (GIS) component into the course for the second year's case study.

\section{Postgraduate education}

\section{Constraints}

In spite of the fact that the course was designated "NET" (which means "fully online" at Waikato), some students had limited home access to computers and broadband, which had to be overcome in order for them to participate in the VC. In fact, in this case study the major constraints were technical, and from the lecturer's perspective, the initial variety and scope of the technical access problems had been unexpected. The extent of advance preparation for the VC experience had also been surprising.

We had a practice session in the week before where the students were invited to join a mock session if you like just to iron out any technical difficulties. In hindsight I should have made that session compulsory rather than optional because as it transpired the ones who didn't show up to the session were the ones that had the technical issues.

The preparation is considerable, and managerially, it's [VC] a lot more difficult to do. It's just a different way of thinking and a different way of organising. But in spite of 
the technical issues I think most of the students seem to feel that it's worthwhile though one or two comments about detracting from the flexibility of the course.... With some of the students being overseas, ... we had different time zones to consider.

Affordances

Overcoming transactional distance was a key objective of the VC and students reported an enhanced sense of connectedness from the experience.

We developed a really good online community, learning community with the participants and what have you, it was fantastic actually, really enjoyed it!

I think definitely the rapport [through the learning community formed] that certainly was huge, that you know, it's a lot bigger because we're teachers of different areas, you know primary, secondary and I'm early childhood, getting on the same page, knowing that we are all at the end of the day teaching in some way, not necessarily in the same environment as each other, that certainly helped a lot with the rapport and knowing.

Although technology afforded enhanced communication opportunities amongst students, it also mediated course design in unanticipated ways. Following feedback from students about the need to have access to a desktop or laptop computer in order to participate in the virtual classroom, the project was extended to include SmartPhones and Adobe Connect Mobile during the second year's case. In addition, changes to how the VC sessions are organised, structured, and facilitated (including making explicit their overall purpose) have been implemented.

\section{Screen and Media Studies}

\section{Constraints}

The flexible nature of the first GIMP layering assignment (no fixed submission deadline), rather than encouraging autonomous learning behaviour, proved highly problematic for first year students in this course. Almost none of them completed the compulsory task until the last six days of the course, much to the consternation of the lecturer.

Having all semester to do the assignment and the bulk [of students] did it in last few days. Despite reminders they trickled in, then a big clump of them at the end. Feedback from students is they overestimated the task and put it off or underestimated it and decided to do it later.

In addition, the lecturer reported that in previous years, in spite of the rigors of scheduling students through the labs, he met and knew the class cohort in its entirety. By removing the requirement for students to attend labs, only a few students sought technical assistance and by the end of the course, the lecturer believed that his lack of interpersonal contact with students had been unsatisfactory.

In terms of how GIMP is going, I don't have real time feedback from students. I ask tutors to make efforts to find out who is doing it and it varies from one tutorial group to another. Some have inertia. Not sure how people are drawing on exemplars that are there.

Affordances

In spite of drawbacks, the lecturer did find that the quality of the creative work produced by the students was higher than in earlier years, which encouraged him to persist with a blended e-learning approach. 
Lecturer: They get it .... they appreciate why I'm doing it and the benefit they are getting. It's not a "learn it for this course and then flush it" - they can see they can build upon it and they can see things they can use it for themselves, so in that sense it seems to be working quite well.

Student: But because of the software, it enabled you to actually create that image to what you're thinking ... The most difficult thing to get into your mind is that it works on layers, transparent layers. So if you are going to alter something, you must have the top layer selected because then you are altering the very front thing. That was the biggest issue for me, just understanding how the layers worked. Once you understood that, then you can manipulate your images as much as you like.

Finally, for the second year case the lecturer amended key parts of the assessment criteria and placed more emphasis on framing the exercise so as to clarify its purpose for students. In particular, he added a more detailed theoretical explanation of the GIMP software and provided that information early in the course.

\section{University preparation (academic literacy)}

This case study proved the least successful of all, at least as regards original expectations, but it did provide the team with different insights into e-learning. The case study began in one pre-degree course, but in spite of extensive researcher effort, essentially none of the students accessed the online workshops. Eventually, we expanded the case to a second pre-degree course in which the teacher used Moodle regularly and was motivated to expand her own and students' computing skills and awareness. However, even these students lacked an interest in the online workshops although the lecturer found the Moodle environment useful for distributing information to students and emailing them individually.

It's been good for me to be secure that I've given them the main information they need. I can say "it's on Moodle". Second, as a way to communicate with them [students], just to email individual people, to get to know who people are, by looking at their photos. On CUP it's really important we know who individual students are.

It is worth noting that the online workshops were generally available to students within the wider university community and were accessed frequently and evaluated positively. We concluded that it was not the workshop material itself that was of limited interest to students, but rather other contextual factors were affecting students' perceptions of the value of such resources for their learning. Here the online survey results proved useful as this cohort's responses differed from the other case study participants. The bridging students were much more negative in their perception of the usefulness of technology for learning. In response to the question about how they preferred to receive detailed feedback from their lecturer on assignments, CUP students overwhelmingly wanted a face to face meeting or to receive hand-written comments on paper, while students in the other cases preferred their feedback in Moodle or email.

Upon reflection we concluded that the pre-degree students, comprised as they were of school leavers who had not achieved university entrance and older adults unused to formal academic study, were facing a number of challenges related to learning and were possibly not ready for the self-paced independent work in the online workshops. Instead students valued and needed a much more affirming, face to face relationship with their teacher. As regards this case study, at the end of 2009 funding for pre-degree 
university programs at our university was fundamentally changed, which has meant that a different case study replaced it during the second year of the project.

\section{Discussion}

Whitworth (2006) in his discussion of research into e-learning environments advocates a holistic and participatory approach, but acknowledges that such a method potentially can lead to competing interpretations of research results. In our context findings from the multiple case studies did not lead to competing views, possibly because of the range of our teaching areas. On the contrary our regular and shared "conversations" about technology and its role in teaching and learning have been highly effective for extending our experience of scholarship into teaching and learning in technology-supported environments (Shulman, 1999).

Activity theory as a framework for the case studies helped us to identify and make explicit the constraints and affordances of different e-learning approaches. Although Murphy and Rodriguez-Manzanares (2008) were examining school settings, we also found that "activity theory allows for a focus on the day to day classroom activity of teachers and the institutional department of school-wide level, where the collaboration of teachers and others might result in the transformation of activity" (p. 3). Members of the research team had multiple opportunities to reexamine their pedagogical assumptions, learning objectives, and e-learning approaches. The use of technology mediated students' learning while the multiple case studies and a collaborative research team environment mediated the co-construction of our new understanding of what was occurring in the classroom.

Three themes that emerged across the case studies will be explored briefly. The first is that e-learning provides effective means for dealing with diverse and changing tertiary cohorts but needs careful curriculum design and monitoring. Second, e-learning tools can help bridge students' conceptual, visual, and spatial thinking from the virtual to the real world. Third, not all students enjoy using technology as it challenges them to conceptualise new and different ways of learning. This last finding links firmly into the first - e-learning integration needs careful curriculum design and monitoring.

\section{Curriculum design and monitoring}

The research team members realised the importance of contextualising software tools within the learning expectations of the specific cohort and students' competencies and literacies. While core concepts of a discipline might evolve slowly over time, student cohorts and e-learning approaches to teaching change more rapidly and affect teachers' development of learning activities and assessed tasks. Although all of the first year case study researchers were experienced computer users, the degree of individual up-skilling involved in preparing for teaching and assuming an e-learning approach in their case study was non-trivial. Each researcher needed to test new software applications, adapt them to their particular teaching contexts, and in most cases prepare documentation to accompany software use - making the initial setup time considerable. We would conjecture that for many academics where e-learning is not a top priority, such demands could present an insurmountable hurdle. In fact, Divaharan and Lim (2010) cite a lack of time as one of the key factors influencing teachers' decisions to not integrate e-learning into their teaching. 


\section{Visual spatial thinking}

In two of the case studies (Earth and Ocean Sciences and Screen and Media Studies) lecturers sought to exploit the potential of e-learning to help develop students' visual spatial thinking. For example, in Screen and Media Studies, students need to understand the complexity of layering visual content to produce sophisticated and textured digital images. Across both disciplines students needed to use imagery and narrative to design, develop, and express abstract concepts such as visual depth, energy, and space (Edelson, 2001). A key finding in this research was that visualisation software, such as GE and GIMP could scaffold students' emergent visual spatial thinking and conceptual understanding. Specifically, the e-learning approach provided students with opportunities to perceive multiple layers of detail in visual representations and taught them how to use authentic "tools of the trade" - tools akin to those they would use in their professional careers. Although in this research we found that e-learning did contribute to the development of visual spatial thinking and helped scaffold students' conceptual learning, the practical realities of a lack of appropriate resourcing and time constraints presented limitations. Nevertheless, the most serious constraints were pedagogical and lecturers needed opportunities to reflect on course planning, structuring, and assessment issues (Clark 2009; Crook 2008).

\section{Not all students liked e-learning}

The final theme relates to the nature of technology itself and teacher and students' needs in order to exploit its potential. Although there were many positive outcomes identified in this research, not all students liked an e-learning approach and all of the lecturers struggled with it at least some of the time. Major challenges were how best to facilitate lecturers' use of technology in integrated and transparent ways to support learning, to develop students' understanding of, and willingness to use e-learning, and to provide timely, appropriate, and affordable support. There are major pedagogical, professional development, training, and resourcing implications related to this theme.

\section{Conclusion}

The imaginative use of e-learning tools to bridge the virtual and the real domains, to develop visual spatial thinking, to stimulate more cohesive online communities, and to provide opportunities for learning academic literacy skills have contributed new and different opportunities for learning in our university environment. In this research the learning has extended beyond the students to the research team as a group of practitioners from across different disciplines.

Nevertheless, the adoption of innovative e-learning support for university teaching is complex, intellectually demanding, and takes time. A challenge for tertiary institutions will be to create teaching and learning environments that encourage, support, and reward research that focuses on enhancing pedagogical change and improved learning outcomes. There must be support for innovative e-learning pedagogy so that it is not considered a time-consuming "add on" to lecturers' work, but is a valued component of tertiary teaching. As was found in this research, along with imaginative use of computing tools, research team members needed multiple opportunities to reflect on and share their teaching experiences within a collegial environment. 
Such practice is consistent with Patel's (2010) definition of the scholarship of teaching in which practitioners engage in ongoing critical reflective practice about teaching, within a public interdisciplinary forum, and with the explicit goal of designing teaching activities such that meaningful learning can occur - arguably the intended objective of all pedagogical undertakings.

\section{Acknowledgments}

The authors gratefully acknowledge funding support from the Teaching and Learning Research Initiative, New Zealand Council for Educational Research, Wellington, New Zealand.

\section{References}

Bakhurst, D. (2009). Reflections on activity theory. Educational Review, 61(2), 197-210.

Black, A. (2005). Spatial ability and earth science conceptual understanding. Journal of Geoscience Education, 53(4), 402-414. http:/ / nagt.org/files/nagt/jge/abstracts/Black_v53p402.pdf

Braun, V. \& Clarke, V. (2006). Using thematic analysis in psychology. Qualitative Research in Psychology, 3, 77-101. https:/ / eprints.uwe.ac.uk/11735/

Clark, R. E. (2009). Translating research into new instructional technologies for higher education: The active ingredient process. Journal of Computing in Higher Education, 21(1), 4-18. http: / / dx.doi.org/10.1007/ s12528-009-9013-8

Cole, M. \& Engestrom, Y. (1993). A cultural-historical approach to distributed cognition. In G. Saloman (Ed), Distributed cognitions: Psychological and educational considerations, pp. 1-46. Cambridge, England: Cambridge University Press.

Convery, A. (2009). The pedagogy of the impressed: How teachers become victims of technological vision. Teachers and Teaching: Theory and Practice, 15(1), 25-41. http: / / dx.doi.org/10.1080/13540600802661303

Crook, C. (2008). Web 2.0 technologies for learning: The current landscape-opportunities, challenges and tensions. http: / / www.becta.org.uk [viewed 1 March 2009]. http:/ / dera.ioe.ac.uk/1475/2/becta_2008_web2_currentlandscapeadditional_litrev.pdf

Divaharan, S. \& Lim, C. P. (2010). Secondary school socio-cultural context influencing ICT integration: A case study approach. Australasian Journal of Educational Technology, 26(6), 741763. http:/ / www.ascilite.org.au/ ajet/ ajet26/divaharan-2.html

Edelson, D. C. (2001). Learning-for-use: A framework for the design of technology-supported inquiry activities. Journal of Research in Science Teaching, 38(3), 355-385. http:/ / dx.doi.org/10.1002/1098-2736(200103)38:3<355::AID-TEA1010>3.0.CO;2-M

Goodfellow, R. (2007). Learning technologies in the university: From 'tools for learning' to 'sites of practice'. In R. Goodfellow \& M. R. Lea (Eds), Challenging e-learning in the university: A literacies perspective, pp. 29-49. Maidenhead, England: Open University Press.

Government of New Zealand (2006). Education Counts. Education attainment of the population. [viewed 15 April 2008]. http:/ / www.educationcounts.govt.nz/statistics/tertiary_education/ retention_and_achievement

Helsper, E. J. \& Eynon, R. (2009). Digital natives: Where is the evidence? British Educational Research Journal, 36(3), 503-520. http: / / eprints.lse.ac.uk/27739/ and http:/ / www.informa world.com / smpp/ content $\sim \mathrm{db}=$ all? content $=10.1080 / 01411920902989227$ 
Johnson, E. M., Cowie, B., De Lange, W. \& Hight, C. (2009). Leveling the playing field: Exploiting technology to enhance tertiary learning. In Same places, different spaces. Proceedings ascilite Auckland 2009.

http:/ / www.ascilite.org.au/conferences/auckland09/procs/johnson.pdf

Johnson, E. M., Haines, A. \& Strang, P. (2009). Transforming our work: E-learning initiatives. In Proceedings of the 2008 annual conference of the Association of Tertiary Learning Advisors of Aotearoa New Zealand, 37-49. Porirua, New Zealand.

Kanuka, H. \& Jugdev, K. (2006). Distance education MBA students: An investigation into the use of an orientation course to address academic and social integration issues. Open Learning, 21(2), 153-166.

Krause, K. L., Hartley, R., James, R. \& McInnis, C. (2005). The first year experience in Australian universities: Findings from a decade of national studies. Centre for the Study of Higher Education. Melbourne, Australia: University of Melbourne. http:/ / www.dest.gov.au/ sectors/ higher _education/publications_resources / profiles/first_year_experience.htm

Kastens, K. A., Manduca, C. A., Cervato, C., Frodeman, R., Goodwin, C., Liben, L. S., Mogk, D. W., Spangler, T. C., Stillings, N. A. \& Titus, S. (2009). How geoscientists think and learn. EOS Transactions, 90(31), 265-272. http:/ / dx.doi.org/10.1029/2009EO310001

Lather, P. (1992). Critical frames in educational research: Feminist and post-structural perspectives. Theory into Practice, 31(2), 87-99.

Lincoln, Y. S. \& Guba, E. (1985). Naturalistic inquiry. Beverly Hills, CA: Sage Publications.

Maykut, P. \& Morehouse, R. (1994). Beginning qualitative research: A philosophic and practical guide. London: Falmer Press.

McGrenere, J. \& Ho, W. (2000). Affordances: Clarifying and evolving a concept. In S. Fels \& P. Poulin (Eds), Proceedings of Graphic Interface 2000, pp. 179-186. Montreal: Canadian HumanComputer Communications Society. [viewed 29 Dec 2009, verified 2 Jun 2011]. http:/ / www.cs.ubc.ca/ joanna / papers/GI2000_McGrenere_Affordances.pdf

Means, B., Toyama, Y., Murphy, R., Bakia, M. \& Jones, K. (2010). Evidence-based practices in online learning: A meta-analysis and review of online learning studies. Center for Technology in Learning, U.S. Department of Education. http: / / www2.ed.gov/rschstat/eval/tech/evidence-based-practices / finalreport.pdf

Moore, M. (1997). Theory of transactional distance. In D. Keegan (Ed), Theoretical principles of distance education, pp. 22-38. New York: Routledge.

Murphy, E. \& Rodriguez-Manzanares, M. A. (2008). Using activity theory and its principle of contradictions to guide research in educational technology. Australasian Journal of Educational Technology, 24(4), 442-457. http:/ / www.ascilite.org.au/ajet/ ajet24/murphy.html

Patel, F. (2010). Exploring a model and approach to the scholarship of teaching: The scholarship teaching academy. The Canadian Journal for the Scholarship of Teaching and Learning, 1(1). http: / / ir.lib.uwo.ca/cjsotl_rcacea/vol1/iss1/3/ [viewed 28 July 2010].

Reeves, T. C., McKenney, S. \& Herrington, J. (2011). Publishing and perishing: The critical importance of educational design research. Australasian Journal of Educational Technology, 27(1), 55-65. http:/ / www.ascilite.org.au/ajet/ajet27/ reeves.html

Russell, M. (2007). 'Slicing up the funding pie': Tertiary funding in New Zealand: Where it's been and where it's going. New Zealand Journal of Teacher's Work, 4(2), 111-116. http: / / www.teacherswork.ac.nz/journal/volume4_issue2/russell.pdf 
Salaway, G., Caruso, J. B. \& Nelson, M. R. (2007). The ECAR study of undergraduate students and information technology, 2007. Research study from the EDUCAUSE Centre for Applied Research. [viewed 22 Jul 2008, verified 2 Jun 2011]. http: / / www.educause.edu/ECAR/TheECARStudyofUndergraduateStu/ 161967

Selander, S. (2008). Designs of learning and the formation and transformation of knowledge in an era of globalization. Studies in Philosophy and Education, 27(4), 267-281. http: / / dx.doi.org/10.1007/s11217-007-9068-9

Shulman, L. S. (1999). Visions of the possible: Models for campus support of the scholarship of teaching and learning. Comments made at meetings during November and December. [viewed 5 Aug 2010, verified 2 Jun 2011]. http: / / www.carnegiefoundation.org/ elibrary/visions-possible-models-campus-support-scholarship-teaching-and-learning

Thorpe, M. (2008). Effective online interaction: Mapping course design to bridge from research to practice. Australasion Journal of Educational Technology, 24(1), 57-72. http: / / www.ascilite.org.au/ajet/ajet24/thorpe.html

Wesch, M. (2009). From knowledgable to knowledge-able: Learning in new media environments. [viewed 21 Jan 2009; verified 2 Jun 2011]. http: / / www.academiccommons.org/commons/ essay/knowledgable-knowledge-able

Whitworth, W. (2006). Dynamic but prosaic: A methodology for studying e-learning environments. International Journal of Research and Method in Education, 29(2), 151-163. http: / / dx.doi.org/10.1080/17437270600891556

Authors: Dr E. Marcia Johnson, Faculty of Education. Email: marcia@waikato.ac.nz Assoc Prof Bronwen Cowie, Faculty of Education. Email: bcowie@waikato.ac.nz Dr Willem De Lange, Earth and Ocean Sciences. Email: delange@waikato.ac.nz Dr Garry Falloon, Faculty of Education. Email: falloong@waikato.ac.nz Dr Craig Hight, Screen and Media Studies. Email: hight@waikato.ac.nz Dr Elaine Khoo, Faculty of Education. Email: ekhoo@waikato.ac.nz The University of Waikato, Hamilton, New Zealand.

Web: http: / / www.waikato.ac.nz /

Please cite as: Johnson, E. M., Cowie, B., De Lange, W., Falloon, G., Hight, C. \& Khoo, E. (2011). Adoption of innovative e-learning support for teaching: A multiple case study at the University of Waikato. Australasian Journal of Educational Technology, 27(3), 499-513. http: / / www.ascilite.org.au/ajet/ajet27 / johnson.html 